\title{
Preanalytical evaluation of serum 25-hydroxyvitamin D3 and 25-hydroxyvitamin D2
}

measurements using LC-MS/MS

Asuka Mochizuki ${ }^{\mathrm{a}, \mathrm{b}, *}$, Yoshio Kodera ${ }^{\mathrm{a}, \mathrm{c}, \mathrm{d}, *}$, Tatsuya Saito ${ }^{\mathrm{d}}$, Mamoru Sato ${ }^{\mathrm{a}}$, Kazuyuki Sogawa ${ }^{\mathrm{a}}$,

Motoi Nishimura $^{\mathrm{a}, \mathrm{b}}$, Masayuki Kubota ${ }^{\mathrm{e}}$, Fumio Nomura ${ }^{\mathrm{a}, \mathrm{b}}$

${ }^{a}$ Clinical Proteomics Research Center, Chiba University Hospital, Chiba, Japan

${ }^{\mathrm{b}}$ Department of Molecular Diagnosis, Graduate School of Medicine, Chiba University,

Chiba, Japan

${ }^{\mathrm{c} C e n t e r}$ for Disease Proteomics, School of Science, Kitasato University, Kanagawa,

Japan

${ }^{\mathrm{d}}$ Laboratory of Biomolecular Dynamics, School of Science, Kitasato University,

Kanagawa, Japan

${ }^{\mathrm{e}}$ Thermo Fisher Scientific K.K.

*Contributed equally to this work.

Corresponding Author: Fumio Nomura, Department of Molecular Diagnosis, Graduate

School of Medicine, Chiba University, 1-8-1 Inohana, Chuo-ku, Chiba City, Chiba 260-8670,

Japan. Tel: +81-43-226-2324; Fax: +81-43-226-2324, E-mail: fnomura@ faculty.chiba-u.jp 


\begin{abstract}
Background: Vitamin D testing is increasing worldwide. Although immunoassays are still widely used in Japan for the measurement of serum 25-hydroxyvitamin D (25OHD) as an indicator of vitamin D status, development of a simple and high-throughput MS-based method is still needed for routine use in clinical laboratories.
\end{abstract}

Methods: We designed a method using a triple quadrupole mass spectrometer equipped with a two-step separation approach that used the Aria TLX-2 HPLC system in the selected reaction monitoring mode. Analytical performance of the system and effects of various preanalytical factors were tested.

Results: High-throughput quantitative analysis of 25OHD3 and D2 at $15 \mathrm{samples} / \mathrm{h}$ was achieved using $25 \mu \mathrm{l}$ of serum/plasma. Intra- and inter-assay CVs for $25 \mathrm{OHD} 3$ was $5 \%$ and $7 \%$, respectively. Limit of detection for $25 \mathrm{OHD} 3$ was $0.31 \mathrm{ng} / \mathrm{ml}$. No significant effects were seen for clotting time, repeated freeze-thaw cycles, anti-coagulants and possible interfering substances. A good correlation $\left(\mathrm{r}^{2}=0.947\right)$ was found between the present system and the DiaSorin radioimmunoassay. Serum 25OHD3 levels in apparently healthy Japanese subjects were $25.5 \pm 9.8 \mathrm{ng} / \mathrm{ml}$ for men and $20.9 \pm 7.1 \mathrm{ng} / \mathrm{ml}$ for women. Conclusions: This high-throughput LC-MS/MS 25-OHD assay has the potential to be used as a routine clinical laboratory assay for assessing vitamin D status.

Keywords: 25-hydroxyvitamin D, serum, plasma, liquid chromatography-tandem mass 
spectrometry, clinical application, selected reaction monitoring

\section{Abbreviations}

1,25(OH) 2 D, 1 $\alpha, 25$-dihydroxyvitamin D; 25OHD2, 25-hydroxyvitamin D2; 25OHD3, 25-hydroxyvitamin D3; APCI, atmospheric-pressure chemical-ionization; FTU, formazin turbidity unit; SRM, selected reaction monitoring 


\section{Introduction}

Vitamin D is a fat-soluble steroid hormone that plays a key role in calcium homeostasis in the body. The two forms of vitamin D, vitamin D3 and D2, are obtained from the diet. However, only vitamin D3 can be formed by exposure of the skin to sunlight. Vitamin D3 and D2 are metabolized to 25-hydroxyvitamin D3 (25OHD3) and 25-hydroxyvitamin D2 (25OHD2) in the liver. The circulating liver metabolites 25OHD3 and D2 can be used as markers of the vitamin D status, as they have a long half-life in the blood and their concentrations are considered to be in equilibrium with the vitamin $\mathrm{D}$ in the body. Both forms of vitamin $\mathrm{D}$ are metabolized in the kidney to $1 \alpha, 25$-dihydroxyvitamin $\mathrm{D}\left(1,25(\mathrm{OH})_{2} \mathrm{D}\right)$ [1]. Vitamin D deficiencies have been reported to be associated with risks of various types of cancer, autoimmune diseases, and cardiovascular diseases [2-5]. A recent report has shown that there is an association between the vitamin D concentration and all-cause mortality [6]. Vitamin D deficiency in adults can exacerbate osteopenia and osteoporosis, which is the leading cause of osteomalacia and muscle weakness, thereby increasing the risk of fracture $[7,8]$. Thus, serum 25OHD measurements have a significant impact on clinical and preventive medicine.

Serum 25OHD levels have been conventionally measured by immunological methods. However, immunoassays are mainly limited by the cross-reactivity of the antibodies and the non equimolar recognition of the 25OHD3 and 25OHD2 forms of the 25OHD metabolites [9]. 
In countries where vitamin D2 containing supplements are available, it is desirable to report separate results for 25OHD3 and 25OHD2. It also has been reported that results given by immunoassays can be affected by occasional changes of the antibody, or the reformulation of reagents [10]. Additionally, methodological differences and between-laboratory variability has also led to a lack of standardization [11-13].

In an attempt to overcome these problems, several liquid chromatography-tandem mass spectrometry (LC-MS/MS) methods have been described for determining 25OHD with an inter-laboratory imprecision similar to most immunoassays [14]. However, several preanalytical steps need to be optimized to improve the throughput prior to any routine use of this LC-MS/MS system for 25OHD measurements in clinical laboratories. This report describes a simple and high-throughput assay for 25OHD3 and 25OHD2 in the serum and plasma using a LC-MS/MS system that is composed of a triple quadrupole mass spectrometer equipped with an Aria TLX-2 HPLC system. This study also determined the effects of various preanalytical factors, such as interference, effect of meals, and sample collection processes, including effects associated with collection tubes and coagulation times.

\section{Materials and Methods}

\subsection{Experimental}

After purchasing calibrators from Chromsystems Instruments and Chemicals $\mathrm{GmbH}$ 
(Munich, Germany), we verified concentrations by using Vitamin D in Human Serum Standard Reference Material (SRM972) as the quality control. SRM972 was from The National Institute of Standards and Technology (Gaithersburg, MD). The suggested values of the 4 Chromsystems calibration standards for 25OHD3 and 25OHD2 were as follows: 6.7 and $0 \mathrm{ng} / \mathrm{ml}$ for the calibrator level $0,19.6$ and $13.1 \mathrm{ng} / \mathrm{ml}$ for calibrator level 1, 33.9 and 25.5 $\mathrm{ng} / \mathrm{ml}$ for calibrator level 2 , and 62.7 and $50.2 \mathrm{ng} / \mathrm{ml}$ for calibrator level 3 , respectively. The suggested 4 quality control values for SRM972 were as follows: 23.9 and $0 \mathrm{ng} / \mathrm{ml}$ in level 1, 12.3 and $1.71 \mathrm{ng} / \mathrm{ml}$ in level 2, 18.5 and $26.4 \mathrm{ng} / \mathrm{ml}$ in level 3, and 33.0 and $2.4 \mathrm{ng} / \mathrm{ml}$ in level 4 for 25OHD3 and 25OHD2, respectively. Hexadeuterated 25OHD3

(25-hydroxycholecalciferol-26,26,26,27,27,27-d6) was used as the internal standard (Medical Isotopes Inc., Pelham, NH).

\subsection{Standard sample handling procedures}

After collecting serum samples in Vacutainer transparent blood collection tubes (4S1001, Insepack $^{\mathrm{TM}}$ II-D, Sekisui Medical Co., Ltd., Tokyo, Japan) that contained SiO2 as a coagulation enhancer and a separating gel, they were left at room temperature for $1 \mathrm{hr}$.

Supernatants were then obtained by centrifugation at $2,200 \times g$ for $10 \mathrm{~min}$ at $4^{\circ} \mathrm{C}$. Plasma samples were collected in Vacutainer transparent blood collection tubes (4E4090, Insepack ${ }^{\mathrm{TM}}$ II-D, Sekisui Medical Co., Ltd.) that contained EDTA potassium $(1.5 \mathrm{mg} / \mathrm{ml})$ as the 
anti-coagulant. Sample aliquots of $25 \mu \mathrm{l}$ were stored at $-80^{\circ} \mathrm{C}$ until analysis.

Low and medium serum control pool samples were obtained from 12 healthy volunteers with a mean age of $29.9 \pm 7.5 \mathrm{y}$ (range, $21-45 \mathrm{y}$ ). To assess the preanalytical factors of 25OHD, serum and plasma samples were also obtained from 4 healthy volunteers, with a mean age of $27.3 \pm 5.9 \mathrm{y}(4-36 \mathrm{y})$. To investigate the influence of meals on the serum values, we recruited 8 men, who had a mean age of $33.8 \pm 3.7 \mathrm{y}(27-38 \mathrm{y})$. The effects of the anti-coagulants or the separating gel on the $25 \mathrm{OHD}$ results were investigated by examining serum and plasma samples obtained from six healthy volunteers, with a mean age of $27.5 \pm$ 4.9 y (24 - 36 y). To obtain reference intervals, a total of 120 healthy subjects (60 men and 60 women) were recruited from patients undergoing medical checkups at Kashiwado Hospital in Chiba, Japan. The mean age of the subjects was $49.3 \pm 14.9$ y (24 -73 y) for men and $49.5 \pm$ 15.7 y $(23-80$ y) for women. The Ethics Committee of our institute approved the study protocol, and each subject provided informed consent prior to their enrollment in the study.

\section{3. $25 O H D$ measurement}

A total of $50 \mu \mathrm{l}$ of acetonitrile with internal standard $(75 \mathrm{ng} / \mathrm{ml})$ was added to $25 \mu \mathrm{l}$ of each sample. After vortexing the mixture for $30 \mathrm{~s}$, samples were centrifuged at $15,000 \times g$ for 10 $\min$ in order to create stable pellets of precipitated proteins. After transferring $55 \mu \mathrm{l}$ of supernatant to the vial, $50 \mu \mathrm{l}$ of the mixture was analyzed by LC-MS/MS. The raw signals for 
25OHD3 and 25OHD2 were normalized to the internal standard 25OHD3-d6 signal.

Concentrations were then calculated based on the 4-point calibration curves determined from the analysis of the samples purchased from Chromsystems Instruments $(0-62.7 \mathrm{ng} / \mathrm{ml}$ for $25 \mathrm{OHD} 3$ and $0-50.2 \mathrm{ng} / \mathrm{ml}$ for $25 \mathrm{OHD} 2)$.

The LC-MS/MS analysis was performed on a TSQ Vantage triple quadrupole mass spectrometer (Thermo Fisher Scientific Inc., Waltham, MA) coupled with an Aria TLX-2 HPLC system (Thermo Fisher Scientific Inc.) [15]. Samples were ionized using an atmospheric-pressure chemical-ionization (APCI) source. The selected reaction monitoring (SRM) transitions for the ion pairs were: Q1/Q3= 383.29/365.17 m/z for 25OHD3, Q1/Q3=389.35/263.16 m/z for 25OHD3-d6, and Q1/Q3=395.28/377.42 m/z for 25OHD2. The concentrations of 25OHD3, 25OHD3-d6 and 25OHD2 were calculated based on the total intensity of the three transitions of 25OHD3, 25OHD3-d6 and the 4 transitions of 25OHD2, respectively. The Aria TLX-2 HPLC system consisted of a CTC HTC PAL autosampler that was maintained at $10^{\circ} \mathrm{C}$, a vacuum degasser, two binary HPLC pumps (with one used for the first dimensional separation and the other used for the second dimensional separation), and two six-port switching valves for multiplexing, which was automatically controlled by the Aria OS software. To provide the multiplexing capability and increase the throughput, two HPLC systems performed parallel analyses. A TurboFlow column XL C18-P, $0.5 \times 50 \mathrm{~mm}$ (Thermo Fisher Scientific Inc.) was used for the first dimensional separation, while a 
Hypersil GOLD $50 \times 3 \mathrm{~mm}, 5-\mu \mathrm{m}$ analytical column (Thermo Fisher Scientific Inc.) was used for the second dimensional separation. Mobile phases A and B consisted of water containing $0.1 \%$ formic acid and methanol containing $0.1 \%$ formic acid, respectively. The final mixture of mobile phase C contained $40 \%$ acetonitrile, $40 \%$ 2-propanol and $20 \%$ acetone. Information on the gradient program is shown in Online Resource 1.

\subsection{LC-MS/MS method validation}

Low $(10.7 \mathrm{ng} / \mathrm{ml})$ and medium $(17.5 \mathrm{ng} / \mathrm{ml})$ serum control pools and a standard solution (SRM972) were used for assessing assay imprecision. Over 20 consecutive days, 25OHD3 and 25OHD2 were measured with three replicates per day (inter-day), while 25OHD3 was measured with 20 replicates per day (intra-day) using low and medium serum control pools for $25 \mathrm{OHD} 3$ and a standard solution for the 25OHD2 analysis. The limit of detection and the limit of quantification were estimated by using a serial dilution of a low serum control pool for $25 \mathrm{OHD} 3$ and a low standard solution for the 25OHD2. The limit of detection and the limit of quantification were defined as the peaks that gave a signal to noise ratio of 3:1 and 10:1, respectively. Dilution linearity was evaluated by measuring the duplicates of 5 dilutions of the low and medium serum control pools, along with a standard solution for the 25OHD3 and a standard solution for the 25OHD2 analysis. Accuracy was estimated by 4 different concentrations of standard solutions that contained 25OHD3 and a standard solution for the 
25OHD2 analysis. Recovery was determined in duplicate after spiking low and medium serum control pools with two different concentrations of standard solutions that contained 25OHD3. The method was assessed for potential interference by spiking a separate medium serum control pool with bilirubin F, bilirubin $\mathrm{C}$, hemolytic hemoglobin, chyle, and rheumatoid factor (IgM-RF) via the use of Interference Check A Plus and Interference Check RF Plus (Sysmex Co., Hyogo, Japan).

\section{2,5 Assessment of preanalytical factors of 25OHD in serum and plasma}

Serum and plasma sampling, and the handling procedures used to evaluate the preanalytical factors were as follows. (1) To assess the effects of time intervals between the venipuncture and sample separation, serum/plasma samples were collected at room temperature at $0.25,0.5,1,2,4$ and $6 \mathrm{~h}$ after the venipuncture. (2) To estimate the effects of shading, we prepared covered or uncovered blood collection tubes and then performed the serum/plasma separation as per the above procedure (1). Serum/plasma samples used in this experiment were collected on different days from the same subjects that were examined in experiment (1). (3) To assess the effects of leaving serum/plasma samples at room temperature prior to storage at $-80^{\circ} \mathrm{C}$, serum/plasma samples were left at $0.25,0.5,1,2,4$ and $6 \mathrm{~h}$. (4) To test the effects of the freeze-thaw cycles, serum/plasma samples were frozen at $-80^{\circ} \mathrm{C}$ in a deep freezer and then thawed at room temperature for $15 \mathrm{~min}$. Samples 
underwent 1 to 5 freeze-thaw cycles. (6) To estimate the influence of meals on the serum samples, 8 men consumed a sandwich, yogurt and vegetable juice $(615 \mathrm{kCal}$, protein $21.0 \mathrm{~g}$, lipid $25.4 \mathrm{~g}$, carbohydrate $82.6 \mathrm{~g}$ ) at 9 AM. Serum samples were collected before and at 1,2, and $3 \mathrm{~h}$ after the meal. (7) To estimate the effects of the routinely used anti-coagulants or separating gel on 25OHD, samples were collected in Vacutainer blood collection tubes that contained anti-coagulants (EDTA, heparin, sodium citrate) or separating gel. To examine these differences, we investigated VENOjectII blood collection tubes (Terumo Co., Ltd., Tokyo, Japan), (i) serum plain tubes (VP-P070K, no additive). We also examined 6 types of Insepack $^{\mathrm{TM}}$ blood collection tubes (Sekisui Medical Co., Ltd.), (ii) serum tubes (4S1001, separating gel and silica, accelerating clotting agent used as the additive), (iii) serum tubes for rapid coagulation (4Q1060, separating gel and thrombin, accelerating clotting agent as the additive), (iv) plasma tubes (4F2618, dipotassium EDTA $(1.5 \mathrm{mg} / \mathrm{ml})$ and sodium fluoride (1 $\mathrm{mg} / \mathrm{ml}$ ) as the additive), (v) plasma tubes (4E2034, disodium EDTA $(1.5 \mathrm{mg} / \mathrm{ml})$ as the additive), (vi) plasma tubes (4E4090, dipotassium EDTA $(1.5 \mathrm{mg} / \mathrm{ml})$ as the additive), and (vii) plasma tubes $(4 \mathrm{H} 2011$, sodium heparin $(15 \mathrm{IU} / \mathrm{ml})$ as the additive). In the final step, we examined 2 types of Microtainer ${ }^{\circledR}$ blood collection tubes (Becton, Dickinson and Company, Franklin Lakes, NJ), (viii) serum tubes for neonates (365967, separating gel and thrombin, accelerating clotting agent as the additive), and (ix) plasma tubes for neonates (365974, dipotassium EDTA (1 mg/ml) as the additive). 


\subsection{Radioimmunoassay}

SRL Inc. (Tokyo, Japan) determined all of the 25OHD3 serum levels. All results were obtained by performing radioimmunoassay (RIA) using a 25 -Hydroxyvitamin D ${ }^{125}$ I RIA kit (Diasorin, Stillwater, MN).

\section{Results}

\subsection{LC-MS/MS method evaluation}

Tables present the LC-MS/MS assay performance characteristics. The intra-assay CVs were $5.2 \%$ for the low level samples (low) and $4.0 \%$ for the medium level samples (medium) for 25OHD3, while they were $10.6 \%$ for the $25 \mathrm{OHD} 2$. The inter-assay CVs for $25 \mathrm{OHD} 3$ were $7.2 \%$ and $6.6 \%$ for the low and medium, respectively (Table 1). Accuracy values were $94.8 \%$ $-104.5 \%$ for $25 \mathrm{OHD} 3$ and were $125.5 \%$ for $25 \mathrm{OHD} 2$ (Table 2). The extraction recovery was $102.6 \%-106 \%$ for $25 \mathrm{OHD} 3$ (Table 3 ). The results of the dilution linearity tests for 25OHD3 and 25OHD2 are shown in Figures 1A and 1B, respectively. The limits of detection were estimated to be $0.31 \mathrm{ng} / \mathrm{ml}$ for $25 \mathrm{OHD} 3$ and $0.88 \mathrm{ng} / \mathrm{ml}$ for $25 \mathrm{OHD} 2$. The limits of quantification were $0.86 \mathrm{ng} / \mathrm{ml}$ for $25 \mathrm{OHD} 3$ and $1.41 \mathrm{ng} / \mathrm{ml}$ for 25OHD2. A linear response was found for the assays up to at least $70.7 \mathrm{ng} / \mathrm{ml}$ for $25 \mathrm{OHD} 3$ and up to $26.4 \mathrm{ng} / \mathrm{ml}$ for 25OHD2. The potential interference experiments for the 25OHD3 assay were performed 
using interference test kits. Our results indicated that the interference $\%$ change was $4.3 \%$ for a maximum concentration of $18.7 \mathrm{mg} / \mathrm{dl}$ for bilirubin $\mathrm{F}, 3.4 \%$ for a concentration of 19.7 $\mathrm{mg} / \mathrm{dl}$ for bilirubin C, $7.1 \%$ for a concentration of $498 \mathrm{mg} / \mathrm{dl}$ for hemolytic hemoglobin and 8.4\% for a concentration of the 1440 formazin turbidity unit (FTU) for chyle. Furthermore, the potential interference of IgM-RF was $4.4 \%$ for a maximum concentration of $500 \mathrm{IU} / \mathrm{ml}$.

\subsection{Assessment of preanalytical factors of $250 H D$ in serum and plasma}

We assessed the stability of $25 \mathrm{OHD}$ in serum and plasma under several sample conditions.

Figure 2 shows the concentrations of $25 \mathrm{OHD} 3$ in the serum (A) and plasma (B) in both the transparent and shaded blood collection tubes for sitting times (clotting times) of $0.25,0.5,1$, 2, 4 and $6 \mathrm{~h}$ before serum/plasma separation after blood collection. CVs of the concentration ratios between the transparent and shaded blood collection tubes for the 24 data points, $(6$ data points for 4 healthy volunteers), were $4.9 \%$ and $5.6 \%$ for serum and plasma, respectively. The results suggested that light did not influence the concentration of 25OHD3 for either the serum or the plasma. In addition, the concentration was not affected by clotting times for up to at least $6 \mathrm{~h}$ at room temperature. Effects of a long sitting time on the 25OHD3 concentration after serum/plasma separation was also assessed (Fig. 3). As seen in Figure 3, the concentration of $25 \mathrm{OHD} 3$ did not change for sitting times up to at least $6 \mathrm{~h}$, and the CVs of the values for the 6 data points for the serum/plasma of the 4 healthy volunteers at $0.25 \mathrm{~h}$, 
$0.5,1,2,4$ and $6 \mathrm{~h}$ ranged from $1.2 \%-7.7 \%$. Furthermore, we assessed the effect of the freeze-thaw cycles on the 25OHD3 concentration in the serum/plasma (Fig. 4) and the postprandial changes for the serum/plasma 25OHD3 (Fig. 5). Our results showed that repeated freeze-thaw cycles for up to 5 times had no significant effect on the 25OHD3 concentration in the serum/plasma. With regard to the intake of meals in the 8 healthy volunteers, the CVs of the concentrations for the 4 data points ranged from $1.0 \%-6.8 \%$, which suggested that meals did not affect the 25OHD3 concentration during the observation periods. However, the concentrations noted after meals in the 3 healthy volunteers were slightly less than those observed before meals, with the average ratios of the 3 data points after the meals found to be $0.86,0.92$ and 0.94 . These results suggest the possibility that slight decreases in the 25OHD3 concentrations in the serum may be dependent upon the specific individual examined. We additionally investigated the effects of anti-coagulants and separating gel on the $25 \mathrm{OHD}$ assay by examining 4 serum and 5 plasma blood collection tube types (Fig. 6). No significant differences were noted in the 25OHD3 concentrations for any of the blood collection tubes.

\subsection{Comparison of serum 25OHD3 levels measured by an in-house LC-MS/MS and the} commercial RIA in healthy Japanese subjects

The LC-MS/MS method was compared with the commercially available DiaSorin RIA 
measurement method for the 25OHD levels in 120 Japanese healthy subjects (60 men and 60 women). The regression line and correlation coefficient were y $(\mathrm{MS})=1.0041 \mathrm{x}(\mathrm{RIA})-3.381$ and 0.947 , respectively (Fig. 7). The values obtained by the RIA method exhibited a bias of about $4 \mathrm{ng} / \mathrm{ml}$. Inconsistencies were also observed for the 3 standard samples purchased from Chromsystems Instruments. The observed biases were 2.3, 5.3 and $3.6 \mathrm{ng} / \mathrm{ml}$ for level 0 (total concentration of 25OHD3 and 25OHD2: $6.7 \mathrm{ng} / \mathrm{ml}$ ), level 1 (total concentration: $32 \mathrm{ng} / \mathrm{ml}$ ) and level 2 (total concentration: $59.4 \mathrm{ng} / \mathrm{ml}$ ), respectively, which were in good agreement with our calculated regression line. The serum 25OHD3 levels were $25.5 \pm 9.8 \mathrm{ng} / \mathrm{ml}$ in men and $20.9 \pm 7.1 \mathrm{ng} / \mathrm{ml}$ in women (Fig. 8).

\section{Discussion}

In this study, we evaluated analytical and preanalytical performances of the quantification of $25 \mathrm{OHD} 3$ and 25OHD2 in the serum and plasma with a LC-MS/MS device equipped with an Aria TLX-2 HPLC system. It is noteworthy that the sample volume required was as little as $25 \mu \mathrm{l}$, which is much lower than has been required for previously reported LC-MS/MS assays $[12,16]$. Also, the throughput of the present assay was high, with this system able to analyze 350 samples per day. The sensitivity, quantitative accuracy and stability for 25OHD3 were all satisfactory. On the other hand, there was a larger limit for the quantitative analysis for $25 \mathrm{OHD} 2$ as compared to 25OHD3. This may be due to the fact that we used 25OHD3-d6 
as an internal standard for 25OHD2, which increases the variability of the 25OHD2 levels.

We additionally assessed the potential interferences of rheumatoid factor, bilirubin,

hemoglobin and chyle, and consistent with a LC-MS/MS assay study by Wagner et al. [17],

we also found the presence of bilirubin, hemoglobin and chyle did not affect the 25OHD assay.

Our present study assessed the effect of rheumatoid factor for the first time, along with examining 4 kinds of preanalytical factors in healthy volunteer specimens, including sitting time before and after the serum/plasma separation and sensitivity to light. In line with the results of several previous studies [18-24], we found no significant effects for any of these factors. Lissner et al. [18] showed that 25OHD in uncentrifuged blood could be stored at $24^{\circ} \mathrm{C}$ for up to three days without any concentration changes. Ersfeld et al. [19] also showed that serum samples were unaffected and could be stored at $4^{\circ} \mathrm{C}$ for up to 5 days. Furthermore, it has also been shown that the 25OHD levels did not significantly change under artificial light [20] or after 2 days of UV light exposure [21]. In the current study, we also demonstrated that repeated freeze-thaw cycles for up to 5 times had no significant effect on the 25OHD in the serum/plasma, which confirms several previous reports [18-22]. When 25OHD determinations are performed in outpatients, it is most likely these subjects will be unfasted. Since postprandial changes of serum/plasma 25OHD levels have yet to be clarified, the present study examined the effect of meals and found that a standard meal did not 
significantly affect the serum 25OHD levels.

In the current study, we tested whether there were changes in the serum/plasma 25OHD levels depending on the type of blood collection tube used. Our results showed there were no significant differences noted in the 25OHD3 concentration. Yu et al. [25] assessed the effects of three types of collection tubes including a plain tube for serum and tubes using heparin and EDTA as anti-coagulants for plasma 25OHD measurements performed by CLIA/LIAISON ${ }^{\circledR}$ and RIA (DiaSorin, Stillwater, MN, USA). Furthermore, Cater examined the effect of a serum separation gel and an anticoagulant on ten kinds of assays, which included LC-MS/MS. Their results indicated that the LC-MS/MS assay was not affected by the type of blood collection tubes used even though some of these assays, such as the IDS iSYS, Roche $25 \mathrm{OHD}_{3}$ and HPLC, are influenced by the types of collection tubes [10]. Our current study may be the first report to have extensively tested whether serum/plasma 25OHD levels determined by LC-MS/MS may differ depending upon the blood collection tube used.

In the last part of our study, we used LC-MS/MS and RIA to measure serum 25OHD levels of 120 apparently healthy Japanese subjects (60 men and 60 women). Our results showed there was a good correlation between the $25 \mathrm{OHD} 3$ results obtained by the LC-MS/MS and the RIA $\left(r^{2}=0.947\right)$. However, the levels determined by LC-MS/MS were somewhat lower (approximately $4 \mathrm{ng} / \mathrm{ml}$ on average) than those for the RIA. For 25OHD2, the levels were found to be less than the limit of detection. 
There have been many previous studies that have compared the results between the 25OHD levels measured by LC-MS/MS and RIA, with almost all finding that the levels measured by LC-MS/MS were lower than those reported by RIA [26-29]. LC-MS/MS has been used to measure the plasma 25OHD concentrations in 98 healthy postmenopausal Japanese women [26] and in 278 elderly Japanese women (62.1 \pm 11 y) [30]. The mean concentrations of the total $25 \mathrm{OHD}$ determined in these studies were $20.9 \mathrm{ng} / \mathrm{ml}$ and 22.0 $\mathrm{ng} / \mathrm{ml}$, respectively. When using the chemiluminescence protein binding assay (CLPBA) method to measure the 25OHD concentrations of 274 young Japanese women (20.6 \pm 1.4 years), the mean level was reported to be $18.7 \pm 4.8 \mathrm{ng} / \mathrm{ml} \mathrm{[31]}$.

The competitive protein binding assay (CPBA) method has also been used to determine if the serum 25OHD levels change in accordance with the season. In one previous study that measured the levels in 529 Japanese subjects (312 men and 217 women), the mean values were found to be $28.0 \pm 5.1 \mathrm{ng} / \mathrm{ml}$ for men and $26.3 \pm 4.4 \mathrm{ng} / \mathrm{ml}$ for women in July, while they were $22.9 \pm 7.2 \mathrm{ng} / \mathrm{ml}$ for men and $19.4 \pm 6.0 \mathrm{ng} / \mathrm{ml}$ for women in November [32]. A further study has additionally documented that there are higher 25OHD3 levels during the summer versus the winter season [33]. More recently, Okazaki et al. examined vitamin D insufficiency threshold levels and reported finding that a serum $25 \mathrm{OHD}$ level of $28 \mathrm{ng} / \mathrm{ml}$ was necessary for stabilizing PTH at optimal levels [34]. Gutiérrez et al. [35] examined white, Mexican Americans and black subjects and found the mean 25OHD levels in serum were 
$25.6 \pm 0.4,19.5 \pm 0.5$ and $14.8 \pm 0.4 \mathrm{ng} / \mathrm{ml}$, respectively. In healthy Japanese subjects, we determined that the mean levels fell between the values of the white and the Mexican American groups. In the future, reference intervals for 25OHD3 in Japanese subjects will need to be determined in a larger scale study that takes into account both seasonal and ethic differences.

In the current study, we developed a high-throughput LC-MS/MS method coupled with the TLX-2 HPLC system that used as little as $25 \mu \mathrm{l}$ of sample and could be used to perform separate quantifications for serum 25OHD3 and 25OHD2. One of the limitations of this method is that it is not able to separate vitamin D epimers such as 3-epi-25OH-D3. Another potential limitation of our study involves the consistency of the analysis, as the separation performance of the reverse-phase analytical columns tends to become lower and the peak width of the SRM chromatogram becomes slightly broader after a total of 3,000 assays. However, the SRM intensity does not exhibit any changes. In addition, if there is not sufficient washing time for the TurboFlow column, there is a tendency for the background level of the mass chromatography to increase with increasing times of sequential analysis. Therefore, we determined the optimum washing time and then adjusted our assay accordingly. This made it possible to reliably measure data within 200 sequential analyses per a single TLX system. We also estimated the durability of the TurboFlow column to be more than 3,000 assays, provided the column was washed for $2 \mathrm{~h}$ or more after every 200 sequential 
analyses. However, since the TLX-2 HPLC system consists of two HPLC systems that analyze the samples in parallel, this allows us to increase the throughput in addition to checking the reproducibility of the results.

\section{Conclusion}

We developed a LC-MS/MS method coupled with the TLX-2 HPLC system that can be used to perform separate quantifications of serum 25OHD3 and 25OHD2. The results obtained were in good agreement with those obtained by a widely used commercial radioimmunoassay. This LC-MS/MS method may be applicable for routine determination of serum/plasma 25OHD levels in clinical laboratories. Our next step is to use the present system to additionally measure $1,25(\mathrm{OH}) 2 \mathrm{D}$, a study which is currently underway.

\section{Acknowledgements}

This study was supported in part by SENTAN, JST and the Ministry of Education,

Culture, Sports, Science, and Technology of Japan. 


\section{References}

[1] Holick MF. Vitamin D status: measurement, interpretation, and clinical application. Ann Epidemiol. 2009;19:73-8.

[2] Holick MF. Vitamin D deficiency. N Engl J Med. 2007;357:266-81.

[3] Peterlik M, Grant WB, Cross HS. Calcium, vitamin D and cancer. Anticancer Res. 2009;29:3687-98.

[4] Forman JP, Bischoff-Ferrari HA, Willett WC, Stampfer MJ, Curhan GC. Vitamin D intake and risk of incident hypertension: results from three large prospective cohort studies. Hypertension. 2005;46:676-82.

[5] Adorini L, Penna G. Control of autoimmune diseases by the vitamin D endocrine system. Nat Clin Pract Rheumatol. 2008;4:404-12.

[6] Michaëlsson K, Baron JA, Snellman G, Gedeborg R, Byberg L, Sundström J, Berglund L, Arnlöv J, Hellman P, Blomhoff R, Wolk A, Garmo H, Holmberg L, Melhus H. Plasma vitamin D and mortality in older men: a community-based prospective cohort study. Am $\mathbf{J}$ Clin Nutr. 2010;92:841-8.

[7] Lips P. Vitamin D deficiency and secondary hyperparathyroidism in the elderly: consequences for bone loss and fractures and therapeutic implications. Endocr Rev. 2001;22:477-501. 
[8] Bischoff-Ferrari HA, Dietrich T, Orav EJ, Dawson-Hughes B. Positive association between 25-hydroxy vitamin D levels and bone mineral density: a population-based study of younger and older adults. Am J Med. 2004;116:634-9.

[9] Wallace AM, Gibson S, de la Hunty A, Lamberg-Allardt C, Ashwell M. Measurement of 25-hydroxyvitamin D in the clinical laboratory: current procedures, performance characteristics and limitations. Steroids. 2010;75:477-88.

[10] Carter GD. Accuracy of 25-hydroxyvitamin D assays: confronting the issues. Curr Drug Targets. 2011;12:19-28.

[11] Singh RJ. Are clinical laboratories prepared for accurate testing of 25-hydroxy vitamin D? Clin Chem. 2008;54:221-3.

[12] Stepman HC, Vanderroost A, Van Uytfanghe K, Thienpont LM. Candidate reference measurement procedures for serum 25-hydroxyvitamin D3 and 25-hydroxyvitamin D2 by using isotope-dilution liquid chromatography-tandem mass spectrometry. Clin Chem. 2011;57:441-8.

[13] Binkley N, Krueger D, Cowgill CS, Plum L, Lake E, Hansen KE, DeLuca HF, Drezner MK. Assay variation confounds the diagnosis of hypovitaminosis D: a call for standardization. J Clin Endocrinol Metab. 2004;89:3152-7.

[14] Carter GD. 25-Hydroxyvitamin D assays: the quest for accuracy. Clin Chem. 2009;55:1300-2. 
[15] Harlan R, Clarke W, Di Bussolo JM, Kozak M, Straseski J, Meany DL. An automated turbulent flow liquid chromatography-isotope dilution mass spectrometry (LC-IDMS) method for quantitation of serum creatinine. Clin Chim Acta. 2010;411:1728-34.

[16] Bunch DR, Miller AY, Wang S. Development and validation of a liquid chromatography-tandem mass spectrometry assay for serum 25-hydroxyvitamin D2/D3 using a turbulent flow online extraction technology. Clin Chem Lab Med. $2009 ; 47: 1565-72$.

[17] Wagner D, Hanwell HE, Schnabl K, Yazdanpanah M, Kimball S, Fu L, Sidhom G, Rousseau D, Cole DE, Vieth R. The ratio of serum 24,25-dihydroxyvitamin $\mathrm{D}_{3}$ to 25-hydroxyvitamin $\mathrm{D}_{3}$ is predictive of 25 -hydroxyvitamin $\mathrm{D}_{3}$ response to vitamin $\mathrm{D}_{3}$ supplementation. J Steroid Biochem Mol Biol. 2011;126:72-7.

[18] Lissner D, Mason RS, Posen S. Stability of vitamin D metabolites in human blood serum and plasma. Clin Chem. 1981;27:773-4.

[19] Ersfeld DL, Rao DS, Body JJ, Sackrison JL Jr, Miller AB, Parikh N, Eskridge TL, Polinske A, Olson GT, MacFarlane GD. Analytical and clinical validation of the $25 \mathrm{OH}$ vitamin D assay for the LIAISON automated analyzer. Clin Biochem. 2004;37:867-74.

[20] Wielders JP, Wijnberg FA. Preanalytical stability of 25(OH)-vitamin D3 in human blood or serum at room temperature: solid as a rock. Clin Chem. 2009;55:1584-5.

[21] Hollis BW. Measuring 25-hydroxyvitamin D in a clinical environment: challenges and 
needs. Am J Clin Nutr. 2008;88:507S-510S.

[22] Antoniucci DM, Black DM, Sellmeyer DE. Serum 25-hydroxyvitamin D is unaffected by multiple freeze-thaw cycles. Clin Chem. 2005;51:258-61.

[23] Berry JL, Selby PL, Davies M, Martin J. Observations from the UK Supra-Regional Assay Service laboratory for the measurement of Vitamin D metabolites. J Steroid Biochem Mol Biol. 2007;103:477-9.

[24] Lewis JG, Elder PA. Serum 25-OH vitamin D2 and D3 are stable under exaggerated conditions. Clin Chem. 2008;54:1931-2.

[25] Yu CL, Falk RT, Kimlin MG, Rajaraman P, Sigurdson AJ, Horst RL, Cosentino LM, Linet MS, Freedman DM. The impact of delayed blood centrifuging, choice of collection tube, and type of assay on 25-hydroxyvitamin D concentrations. Cancer Causes Control. 2010;21:643-8.

[26] Tsugawa N, Suhara Y, Kamao M, Okano T. Determination of 25-hydroxyvitamin D in human plasma using high-performance liquid chromatography-tandem mass spectrometry. Anal Chem. 2005;77:3001-7.

[27] Saenger AK, Laha TJ, Bremner DE, Sadrzadeh SM. Quantification of serum 25-hydroxyvitamin $\mathrm{D}_{2}$ and $\mathrm{D}_{3}$ using HPLC-tandem mass spectrometry and examination of reference intervals for diagnosis of vitamin D deficiency. Am J Clin Pathol. 2006;125:914-20. 
[28] Singh RJ, Taylor RL, Reddy GS, Grebe SK. C-3 epimers can account for a significant proportion of total circulating 25-hydroxyvitamin D in infants, complicating accurate measurement and interpretation of vitamin D status. J Clin Endocrinol Metab. 2006;91:3055-61.

[29] Maunsell Z, Wright DJ, Rainbow SJ. Routine isotope-dilution liquid chromatography-tandem mass spectrometry assay for simultaneous measurement of the 25-hydroxy metabolites of vitamins $\mathrm{D}_{2}$ and $\mathrm{D}_{3}$. Clin Chem. 2005;51:1683-90.

[30] Tsugawa N, Kamao M, Suhara Y, Okano T. Development of novel serum 25-hydroxyvitamin D determination method and its clinical application. Osteoporosis Japan. 2006;14:679-84.

[31] Ohta H, Kuroda T, Onoe Y, Orito S, Ohara M, Kume M, Harada A, Tsugawa N, Okano T, Sasaki S. The impact of lifestyle factors on serum 25-hydroxyvitamin D levels: a cross-sectional study in Japanese women aged 19-25 years. J Bone Miner Metab. $2009 ; 27: 682-8$.

[32] Nanri A, Foo LH, Nakamura K, Hori A, Poudel-Tandukar K, Matsushita Y, Mizoue T. Serum 25-hydroxyvitamin D concentrations and season-specific correlates in Japanese adults. J Epidemiol. 2011;21:346-53. 
[33] Snellman G, Melhus H, Gedeborg R, Byberg L, Berglund L, Wernroth L, Michaëlsson K. Determining vitamin D status: a comparison between commercially available assays. PLoS One. 2010;5:e11555.

[34] Okazaki R, Sugimoto T, Kaji H, Fujii Y, Shiraki M, Inoue D, Endo I, Okano T, Hirota T, Kurahashi I, Matsumoto T. Vitamin D insufficiency defined by serum 25-hydroxyvitamin $\mathrm{D}$ and parathyroid hormone before and after oral vitamin $\mathrm{D}_{3}$ load in Japanese subjects. J Bone Miner Metab. 2011;29:103-10.

[35] Gutiérrez OM, Farwell WR, Kermah D, Taylor EN. Racial differences in the relationship between vitamin $\mathrm{D}$, bone mineral density, and parathyroid hormone in the National Health and Nutrition Examination Survey. Osteoporos Int. 2011;22:1745-53. 


\section{Figure legends}

Figure 1. Dilution linearity of the 25OHD3 and 25OHD2 LC-MS/MS assay. (A)

low-concentration serum control pool (circle), medium-concentration serum control pool

(triangle) and a standard solution (NIST Level 4) (square) for 25OHD3. (B) standard solution

(NIST level 3) for the 25OHD2 analysis.

Figure 2. Time courses of the 25OHD3 concentrations between the venipuncture and

serum/plasma separation in covered blood collection tubes (gray marks) and uncovered blood collection tubes (opened marks). The diamond, square, triangle and circle marks correspond to the 25OHD3 concentrations in (A) serum and (B) plasma of 4 healthy volunteers.

Figure 3 . Time courses of the $25 \mathrm{OHD} 3$ concentration between serum/plasma separation and storage. The diamond, square, triangle and circle marks indicate 25OHD3 concentrations in the serum (opened marks) and plasma (gray marks) of 4 healthy volunteers.

Figure 4. The effect of repeated freeze-thaw cycles on 25OHD3 concentration of serum and plasma. The diamond, square, triangle and circle marks indicate 25OHD3 concentrations in serum (opened marks) and plasma (gray marks) of 4 healthy volunteers. 
Figure 5. The influence of meals on 25OHD3 concentrations in the serum of 8 healthy volunteers.

Figure 6. The effects of anticoagulants or separating gel on 25OHD3 concentrations. Nine types of blood collection tubes (i-ix) were investigated. The diamond, square, triangle, circle, cross and asterisk marks indicate the 25OHD3 concentrations in the serum of six healthy volunteers.

Figure7. Linear regression analysis of the 120 clinical samples examined by the RIA and LC-MS/MS assays.

Figure 8. Concentrations of 25OHD3 determined in 120 healthy Japanese subjects (60 men and 60 women) by the LC-MS/MS assay. 
Table 1. Inter- and intra-day precision of the LC-MS/MS assay for 25OHD3 and 25OHD2.

\begin{tabular}{lll}
\hline Compound & Inter-day $(\% \mathrm{CV})$ & Intra-day $(\% \mathrm{CV})$ \\
\hline \multirow{2}{*}{ 25OHD3 } & $7.2($ low-level sample) & 5.2 (low-level sample) \\
& $6.6($ medium-level sample) & 4.0 (medium-level sample) \\
25OHD2 & - & 10.6 \\
\hline
\end{tabular}


Table 2. Accuracy of the LC-MS/MS assay for 25OHD3 and 25OHD2.

\begin{tabular}{llllllll}
\hline \multirow{2}{*}{ Compound } & Standard & $\begin{array}{l}\text { Expected } \\
\text { conc. } \\
(\mathrm{ng} / \mathrm{ml})\end{array}$ & $\begin{array}{llllll}\text { average } \\
(\mathrm{ng} / \mathrm{ml})\end{array}$ & & $\begin{array}{l}\text { CV } \\
(\%)\end{array}$ & $\begin{array}{l}\text { Accuracy } \\
(\%)\end{array}$ & $\begin{array}{l}\text { Range } \\
(\%)\end{array}$ \\
\hline 25OHD 3 & Level 1 & $23.9 \pm 0.8$ & 25.0 & 1.0 & 4.0 & 104.5 & $97.5-113.0$ \\
& Level 2 & $12.3 \pm 0.6$ & 12.7 & 0.7 & 5.6 & 103.5 & $91.9-112.2$ \\
& Level 3 & $18.5 \pm 1.1$ & 19.0 & 1.0 & 5.4 & 102.8 & $95.7-118.9$ \\
& Level 4 & $70.7 \pm 2.0$ & 67.0 & 3.6 & 5.4 & 94.8 & $85.1-106.9$ \\
& & & & & & & \\
\hline
\end{tabular}


Table 3. Extraction recovery of the LC-MS/MS assay for 25OHD3.

\begin{tabular}{llllll}
\hline Sample & $\begin{array}{l}25 \mathrm{OHD} 3 \\
\text { conc. } \\
(\mathrm{ng} / \mathrm{ml})\end{array}$ & Spiked conc. & $\begin{array}{l}\text { Expected } \\
\text { conc. } \\
(\mathrm{ng} / \mathrm{ml})\end{array}$ & $\begin{array}{l}\text { Average } / \mathrm{ml}) \\
\begin{array}{l}\text { Extraction } \\
\text { recovery } \\
(\mathrm{ng} / \mathrm{ml})\end{array}\end{array}$ \\
\hline \multirow{2}{*}{ Low pool } & 10.7 & 12.3 & 11.5 & 11.8 & 102.6 \\
Medium & \multirow{2}{*}{17.5} & 23.9 & 17.3 & 18.3 & 105.8 \\
pool & 12.3 & 14.9 & 15.8 & 106 \\
\hline
\end{tabular}


Online Resource 1

LC conditions for turbo and analytical columns.

\begin{tabular}{llllllll}
\hline $\begin{array}{l}\text { Time } \\
(\mathrm{sec})\end{array}$ & \multicolumn{2}{l}{ Turbo flow column } & $\begin{array}{l}\text { Flow rate } \\
\text { (ml/min) }\end{array}$ & $\% \mathrm{~A}$ & $\% \mathrm{~B}$ & $\% \mathrm{C}$ & $\begin{array}{l}\text { Flow rate } \\
(\mathrm{ml} / \mathrm{min})\end{array}$ \\
\hline 30 & 2 & 100 & - & - & 0.7 & $\% \mathrm{~A}$ & $\% \mathrm{~B}$ \\
5 & 2 & 100 & - & - & 0.5 & 70 & 30 \\
90 & 0.2 & 100 & - & - & 0.5 & 70 & 30 \\
20 & 2 & - & - & 100 & 0.7 & 70 & 30 \\
30 & 2 & - & - & 100 & 0.7 & 65 & 35 \\
30 & 2 & 100 & - & - & 0.7 & 40 & 60 \\
195 & 2 & 20 & 80 & - & 0.7 & 10 & 90 \\
50 & 2 & 100 & - & - & 0.7 & 10 & 90 \\
\hline
\end{tabular}




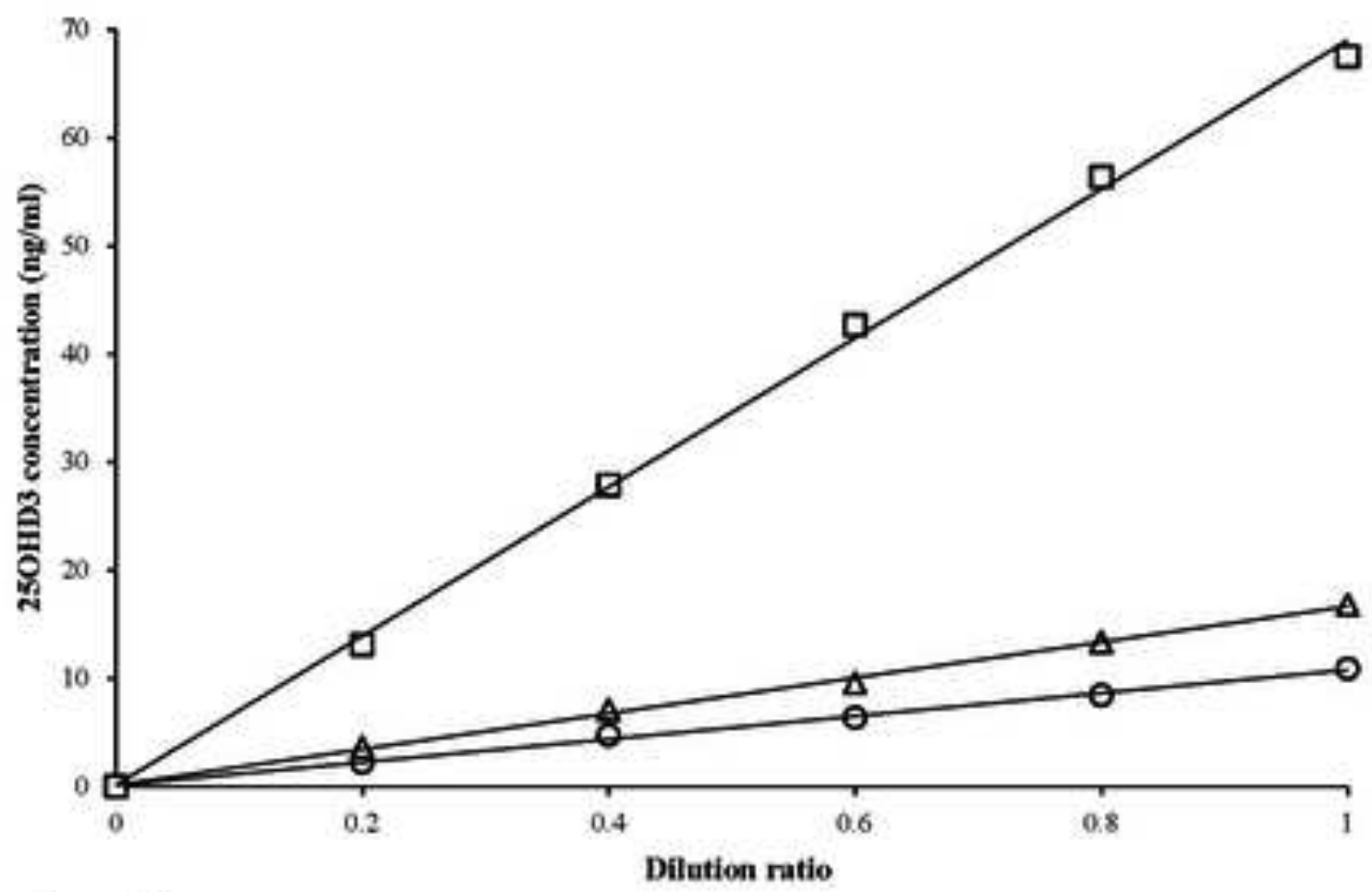

Figure 1A 




Figure 1B

Figure 1B

Dilution natio

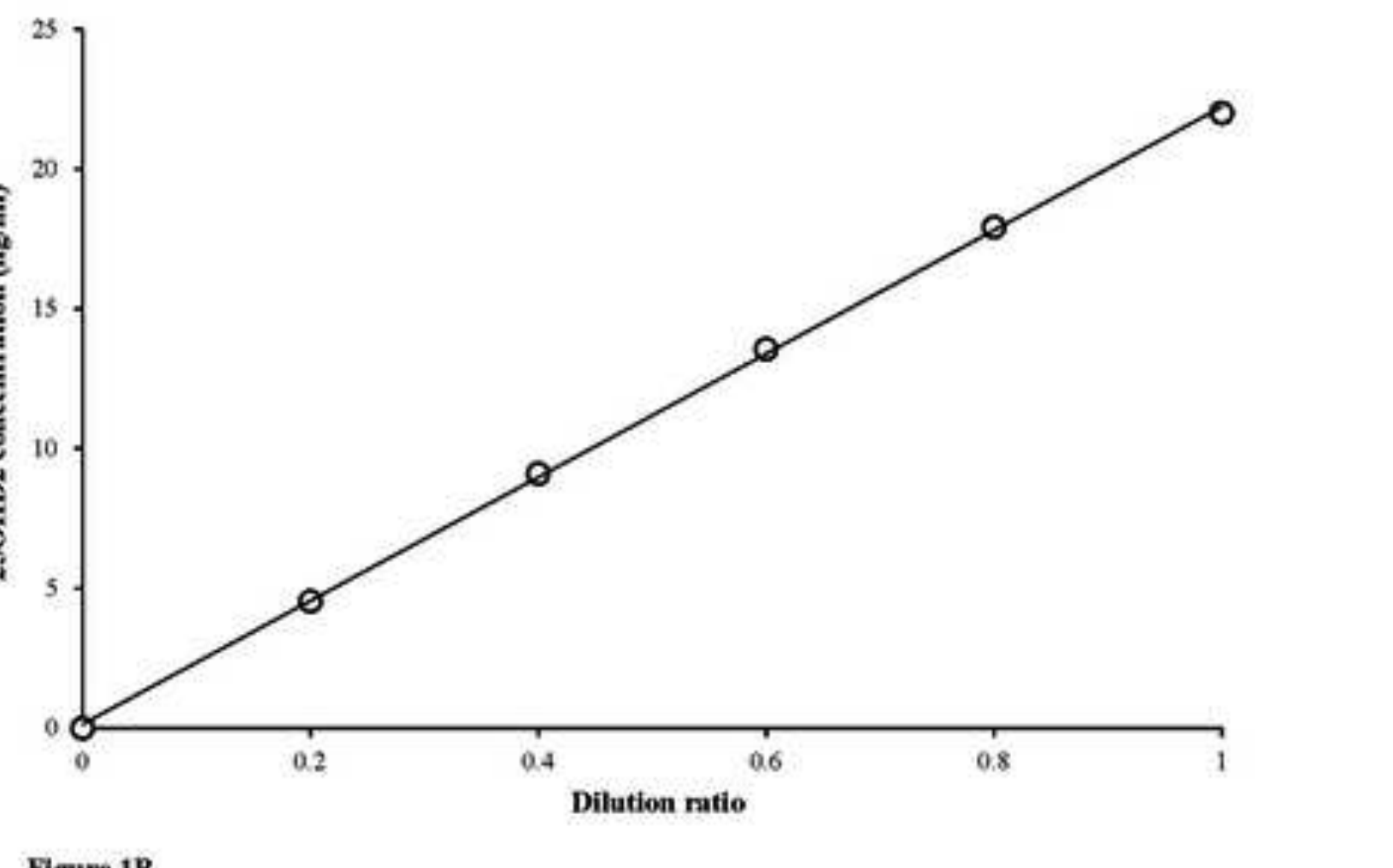

列

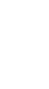

Figure 1B

\section{(}
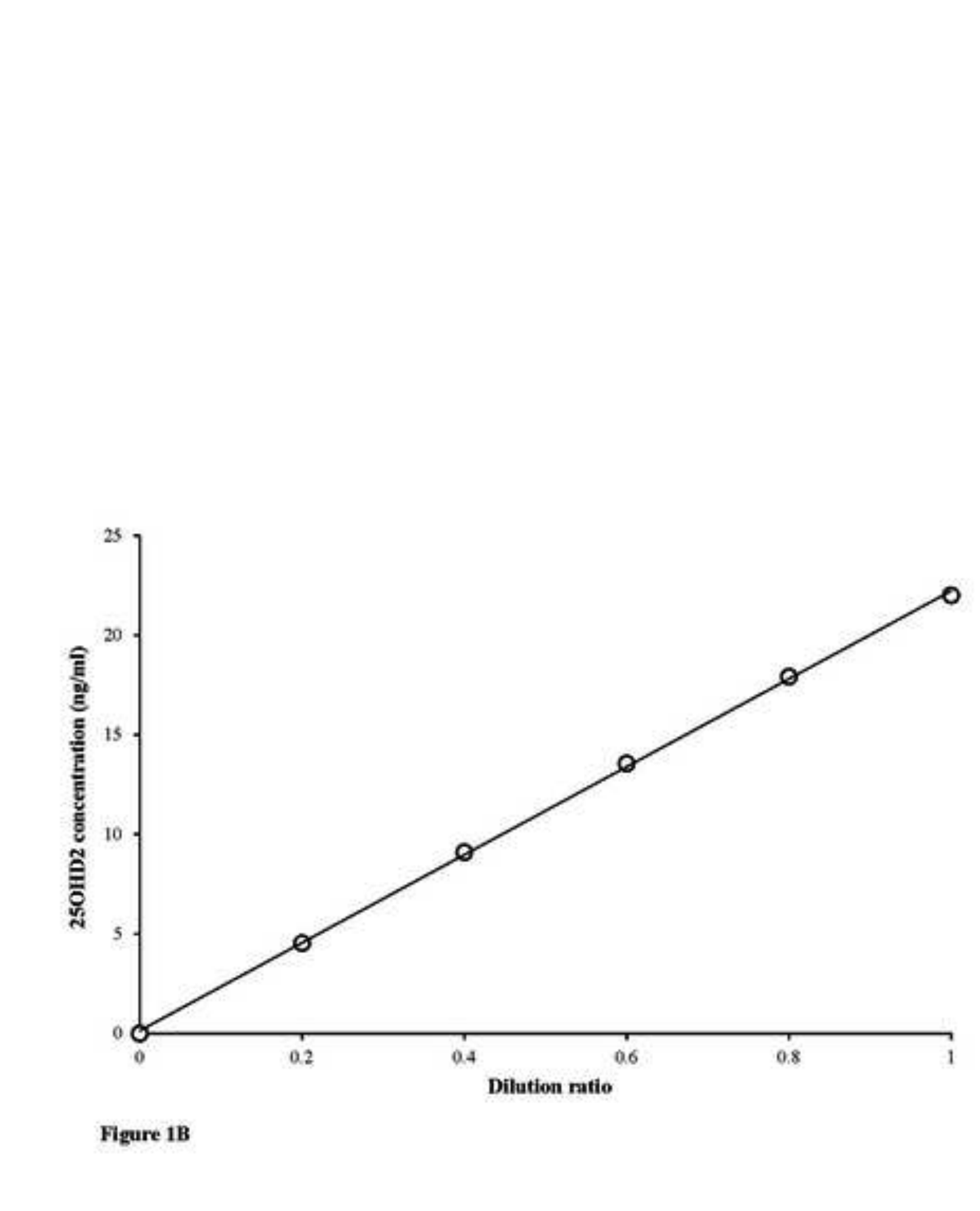
Figure 2A



Figure 2A

Figure 2A a Figure 2A

$+2$

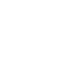

$\sqrt{10}$

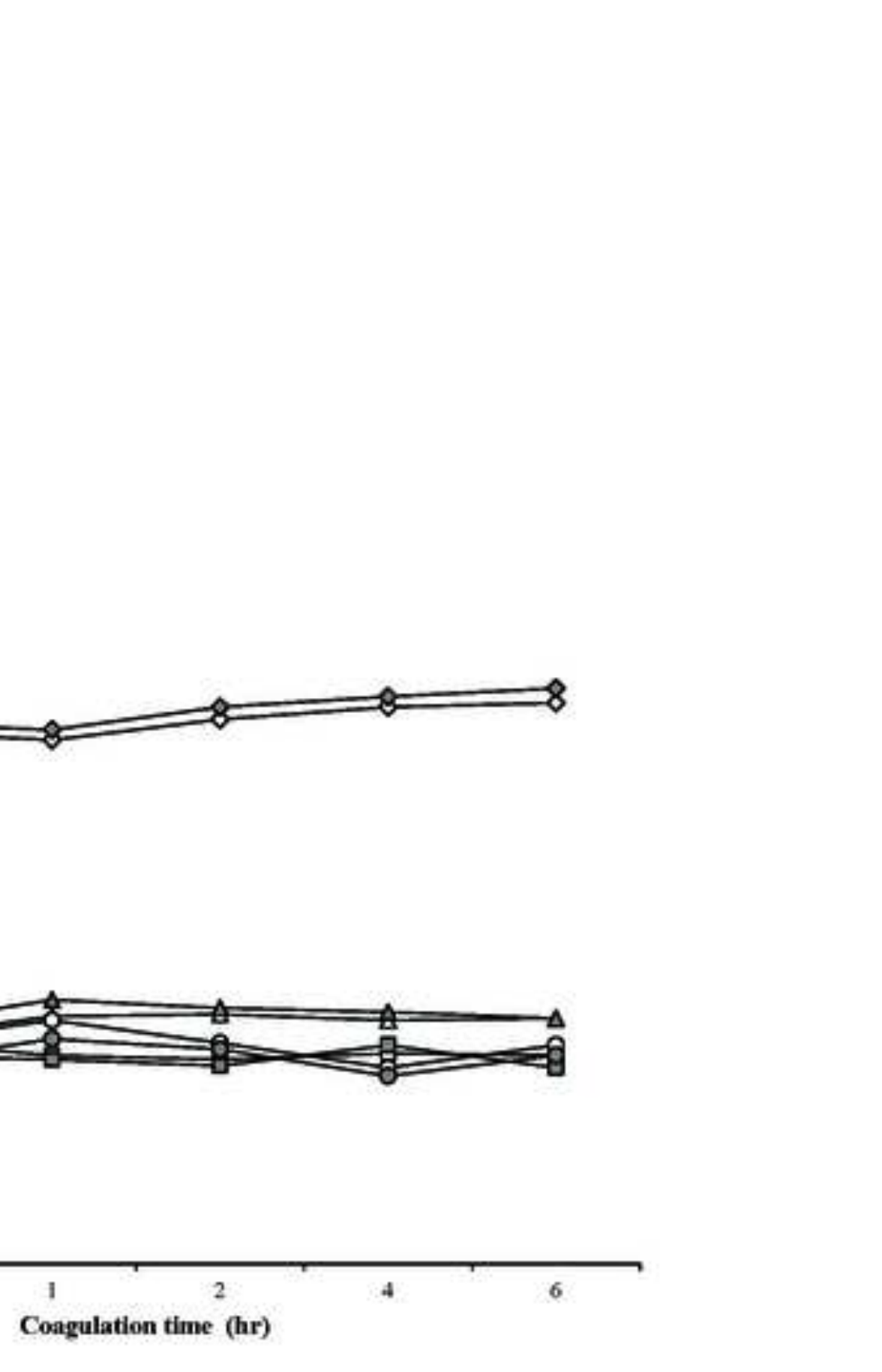

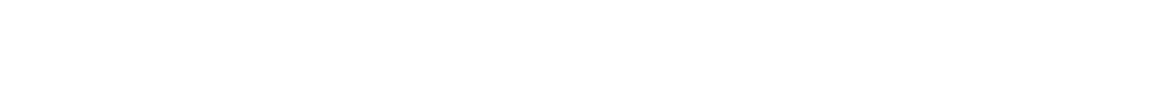

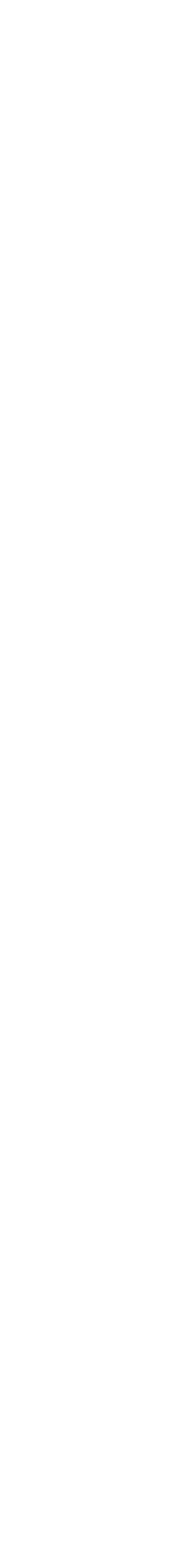

(1)




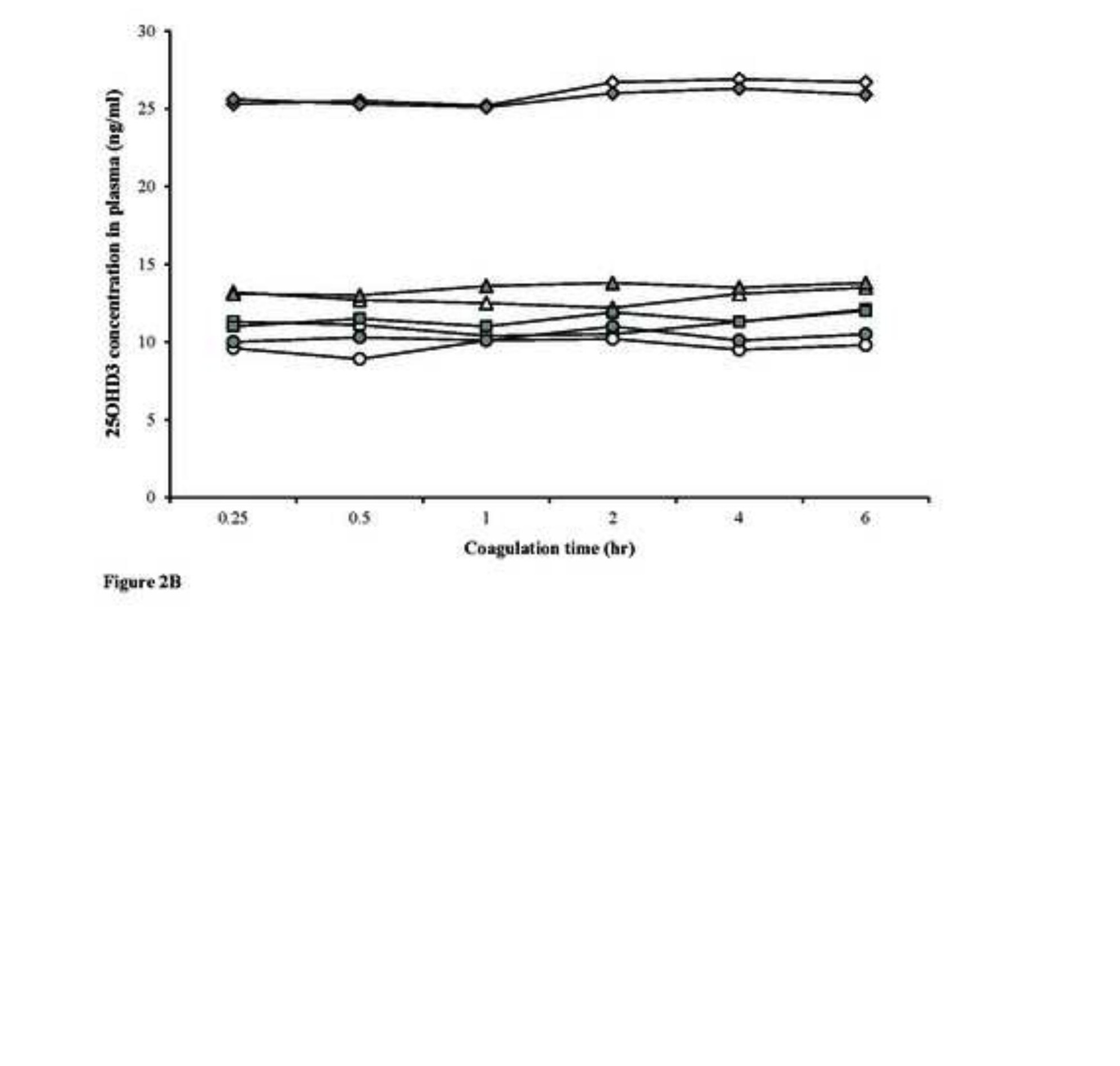

(1)

Figure 2B

(a)

.

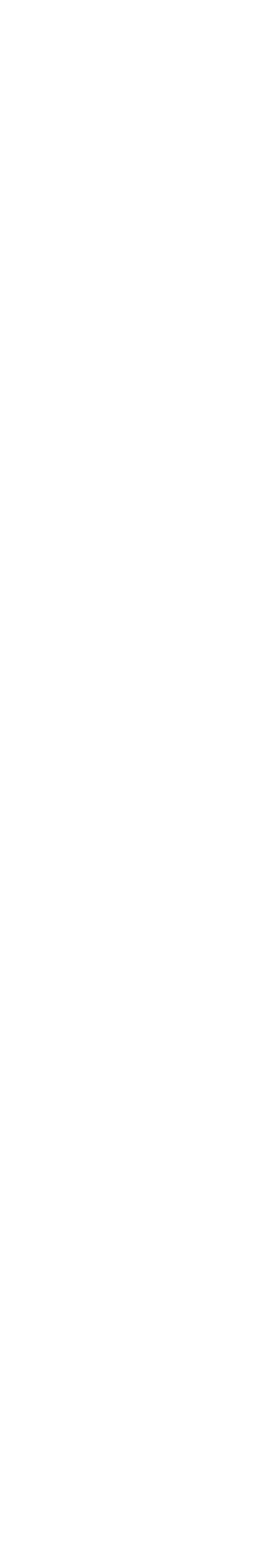

.

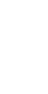

\section{Figure}

(1) 


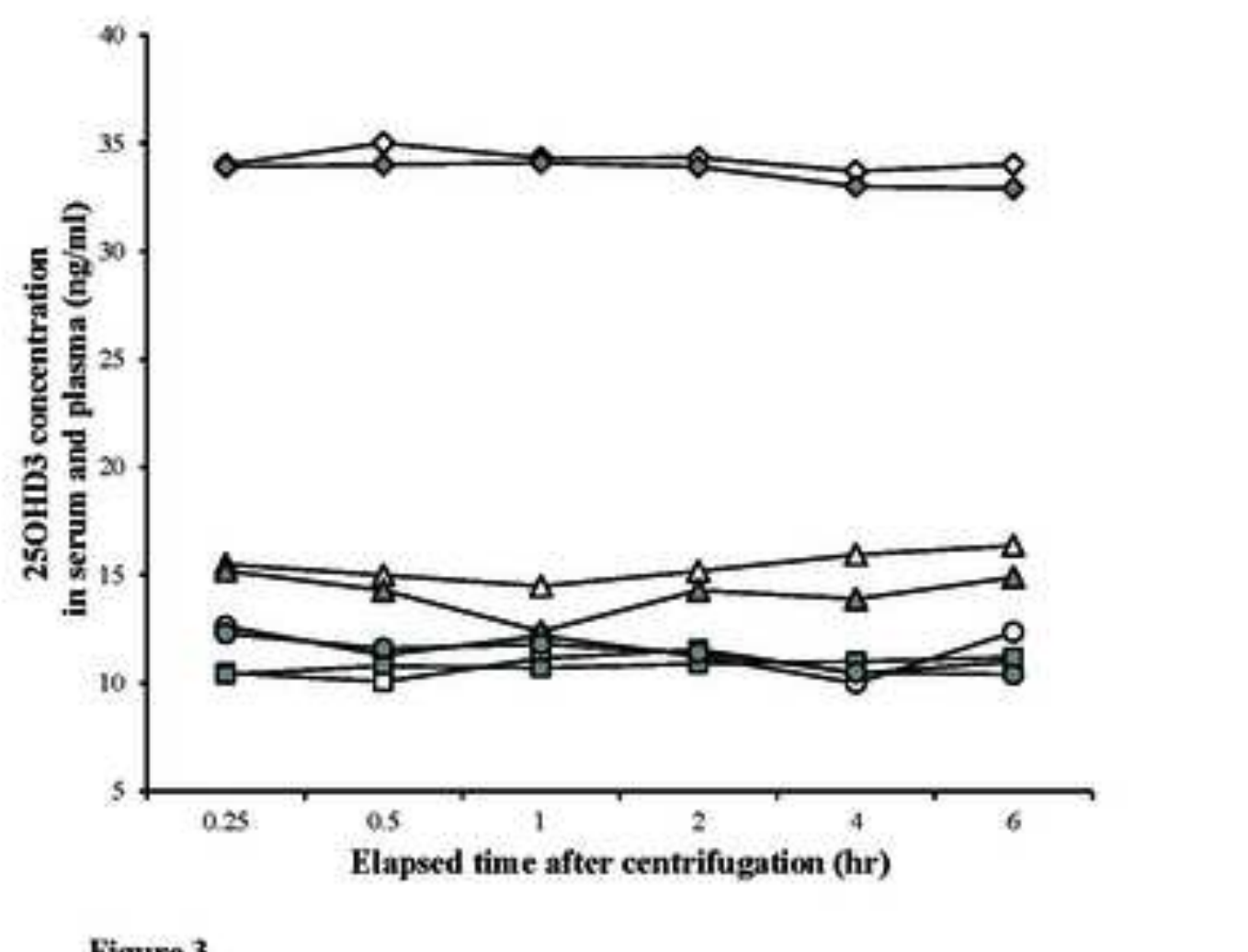

Figure 3

Figure 3



(2)

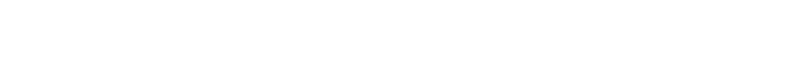

\title{
Elapsed time after centrifugation (hr)
}

.

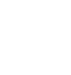

.
\end{abstract}

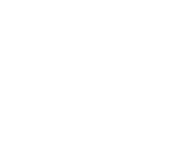

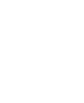


(1)

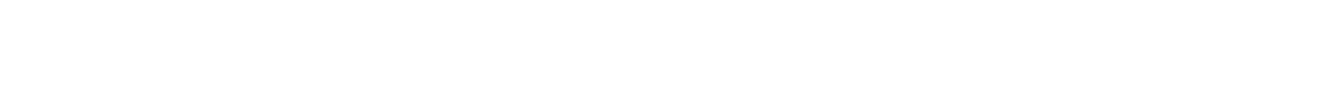
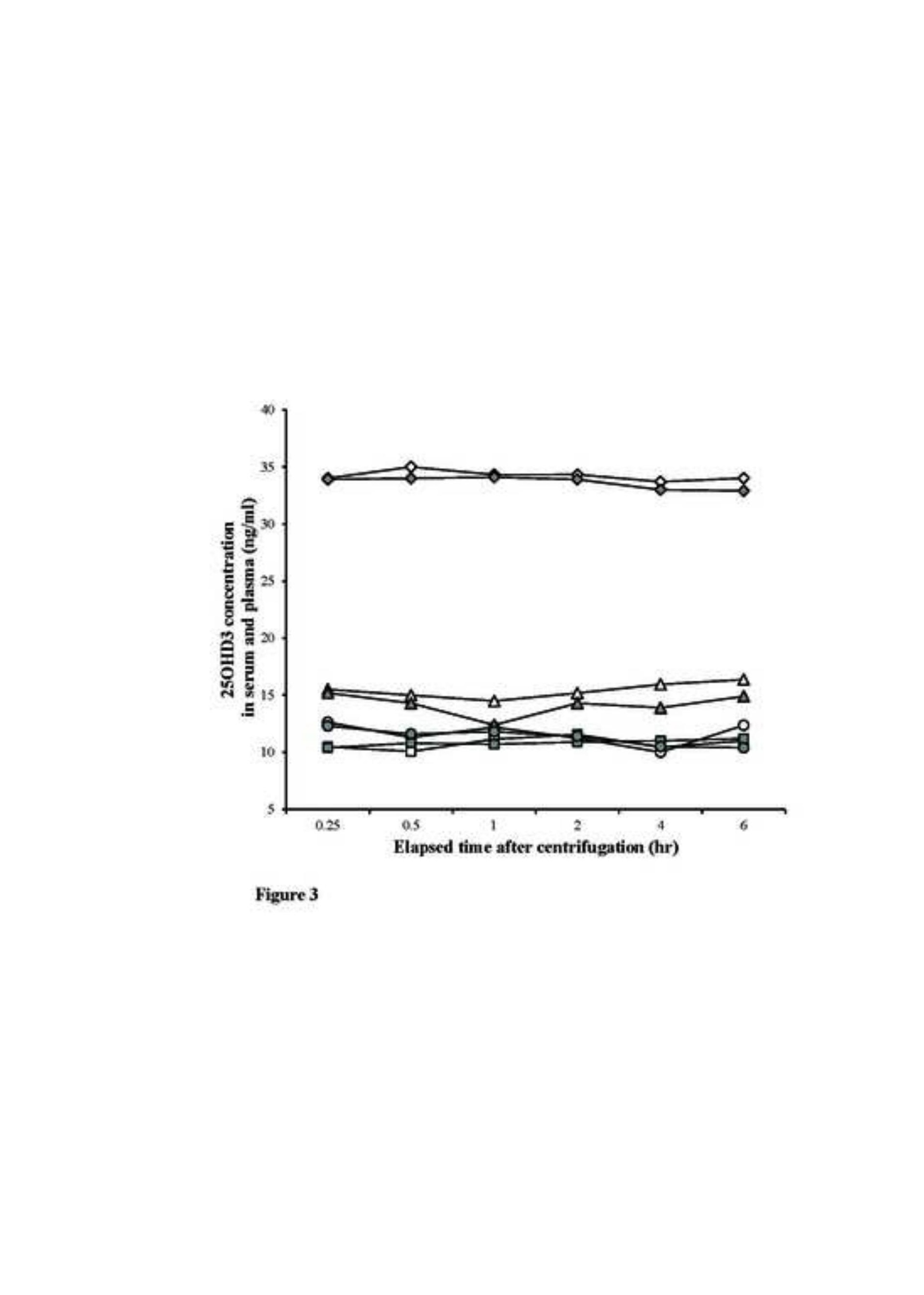




Figure 5

Figure 5

Time after meal (hr)

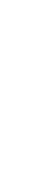

Fure 5

4nי 


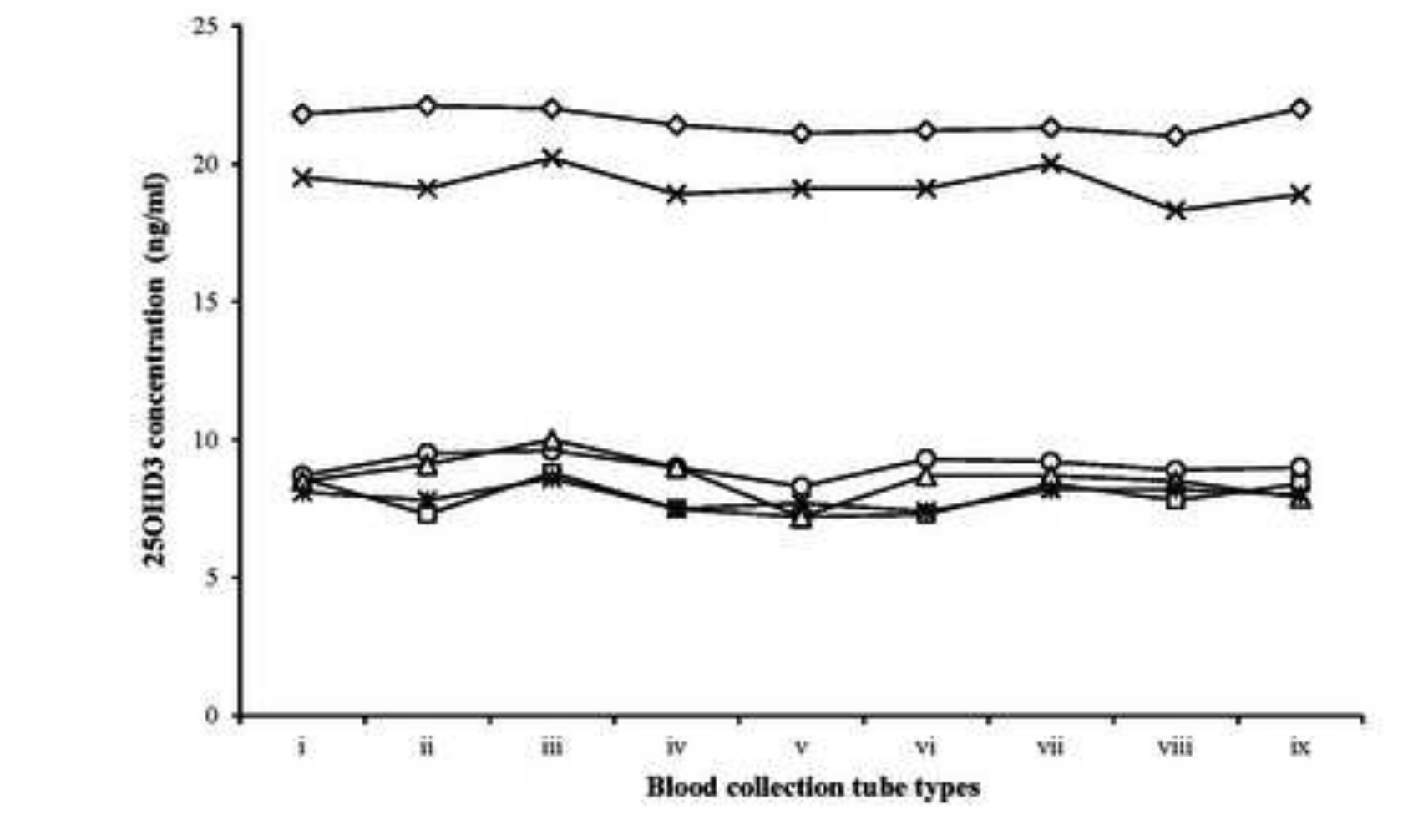

Figure 6

Figure 6

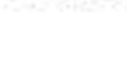

.

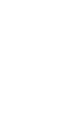

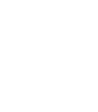






Figure 7

Figure 7

(H) 7

\section{Fure 7} RIA assay (ngat)

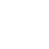




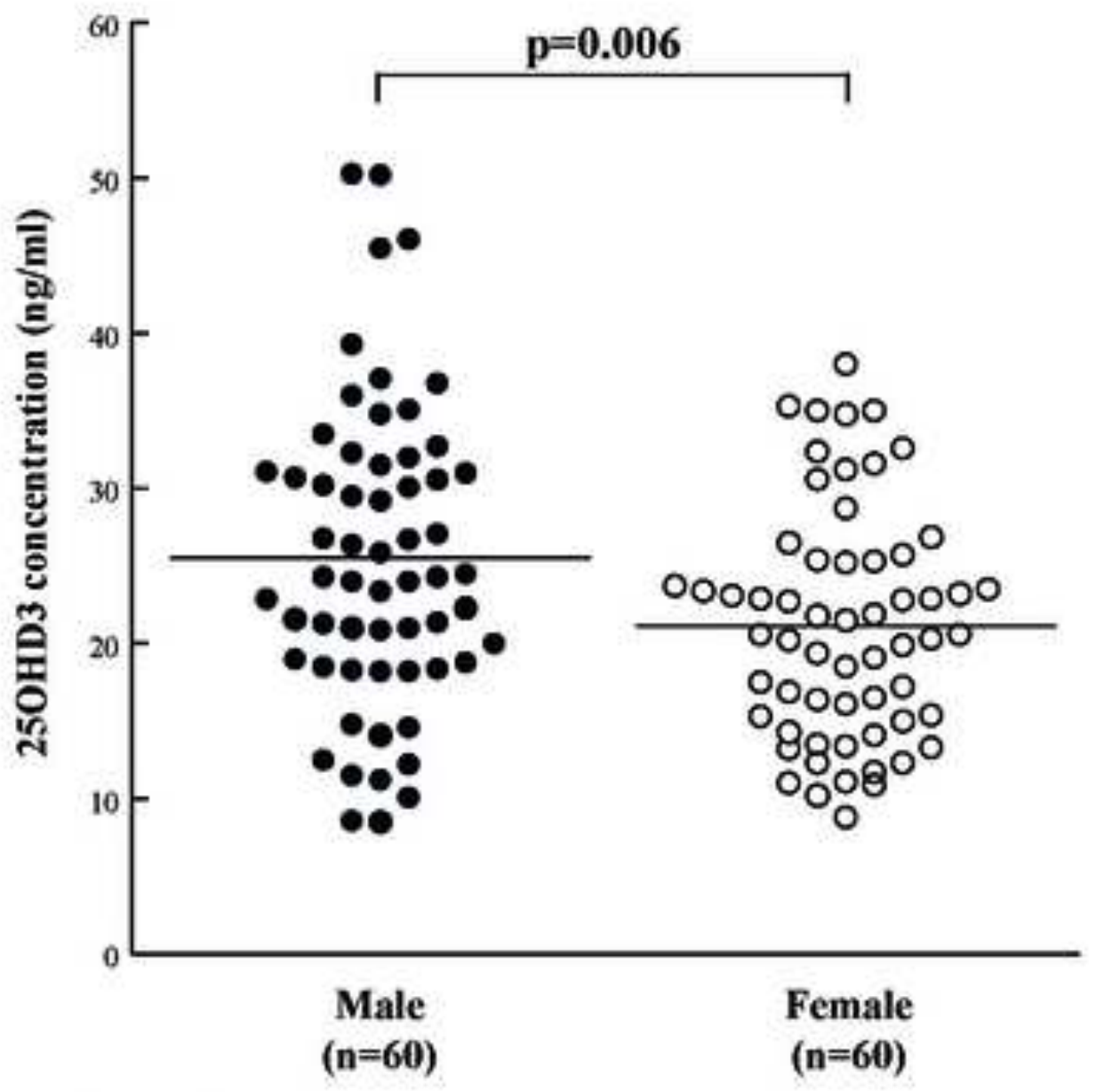

Figure 8

Figure 8

Male
$(n=60)$

$$
\text { ( } \mathrm{n}=60 \text { ) }
$$

